\title{
Audiovisual materials: a way to reinforce listening skills in primary school teacher education ${ }^{1}$
}

\author{
Pilar González-Vera \\ pilargv@unizar.es \\ Ana Hornero Corisco \\ ahornero@unizar.es \\ Universidad de Zaragoza, Spain
}

\begin{abstract}
This paper aims to show the effective use of audiovisual materials in the teaching of EFL to primary school teachers. For that purpose a representative sample of undergraduate students of the Degree in Primary Education with a pre-intermediate B1 level was selected. The students, whose ages ranged from 18 to 22, belonged to the so-called E-generation (Prensky 2001). In the first stage of the study a questionnaire was distributed in order to shed light on our students' level of English as well as on the ways and resources they have used to learn English. It revealed that oral communication skills (listening, speaking and pronunciation) were usually underestimated. Bearing in mind these results, the present study proposed two main activities, one focused on listening comprehension and another on the improvement of pronunciation through audiovisual materials
\end{abstract}

Keywords: CLIL, university, methodology, guidelines, scaffolding, student-centred

\section{INTRODUCTION}

There seems to be no doubt at present that, as experts in the field state, "the momentum of growth has become so great that there is nothing likely to stop the continued spread of English as a global lingua franca" (Crystal 2006: 421). It is easy to understand that, due to the great spread of functionality of English today, many countries have adopted it as "a medium of communication, either for internal or external purposes" (Crystal 2006: 427). However, other professionals of EFL teaching claim that

$1 \quad$ Financial support for this research has been provided to the Swift H 46 Group by the Regional Government of Aragon. 
in too many countries (...) English is still taught with little regard to its practical use. Until all English teachers are teaching English as a tool for communication, countries and individuals will not enjoy the full benefit of a global language (EPI, 5).

Surveys at the European level have proved the weak competence of Spanish users of English $^{2}$. A questionnaire completed in 2012 by 2,000 students of Secondary Education in Aragon revealed that not much time is devoted to listening outside the classroom. According to the students' perceptions, there would seem to be a need to insist on the practice of listening (Hornero et al. 2013, Mur-Dueñas et al. 2013, Plo et al. 2014).

Our own survey evidences the weaknesses of Spanish secondary education students' oral skills in English. Now those students are at university and their oral competence needs urgent improvement. The students, whose ages ranged from 18 to 22, belonged to the so-called E-generation (Prensky 2001), characterised by living surrounded by a digital culture and their ability to perform multiple tasks. These students have a low tolerance for lectures and prefer active rather than passive learning, which leads to a change in the model of pedagogy, "from a teacher-focused approach based on instruction to a student-focused model based on collaboration" (Tapscott 2009). The questionnaire revealed that oral communication skills (listening, speaking and pronunciation) were usually underestimated even though language curricula consider communication as the ultimate goal of learning a language.

When it comes to focusing on Listening skills, the description for the B1 Level provided by the EAQUALS ${ }^{3}$ Bank of descriptors (Figure 1) can be taken as a reference:

\footnotetext{
$2 \quad$ For this purpose, see the results of the 5th edition of the English Proficiency Test, which presents a ranking of 70 countries based on test data from adults who took their online English tests in 2014. Spain is, according to this survey, located in the "moderate band", which corresponds to CEFR level B1.

EAQUALS (Evaluation \& Accreditation of Quality in Language Services) is an international association of institutions and organisations involved in language education whose aim is to promote and guarantee high quality in language teaching and learning. To achieve this aim, EAQUALS has created and published a demanding set of criteria to verify the quality offered by its accredited member-schools.
} 
Figure 1. From the EAQUALS Bank of descriptors.

\section{B1 Level}

\section{OVERALL LISTENING}

I can understand the main points of clear standard speech on familiar, everyday subjects, provided there is an opportunity to get repetition or clarification sometimes

\section{LISTEN TO INTERLOCUTOR}

I can understand what is said to me in everyday conversations, but I sometimes need help in clarifying

\section{LISTEN TO TV AND FILMS}

I can understand the main points in TV programmes on familiar topics when the delivery is relatively slow and clear

Bearing in mind the results of the questionnaire and the above bank of descriptors for the B1 level, the present study proposed two main activities, one focused on listening comprehension and another on the improvement of pronunciation through audiovisual materials, as part of their continuous assessment in the subject English in Primary Education I. Students were given clear instructions for the completion of the tasks based on clips from the British animated children's television series Peppa Pig and Ben and Holly's Little Kingdom. The choice of these clips was justified by the thematic focus that is related to one of the units of the subject and the clarity of the RP (Received Pronunciation) accent used in both series.

\section{LISTENING WITHIN A COMMUNICATIVE LEARNING APPROACH}

Our study aimed to test the efficiency of using audiovisual materials and activities in the training of future teachers, focusing on the improvement of their listening skills. There is no doubt that both extensive and intensive listening provide students with the opportunity to hear different speakers and accents, strengthen their speaking habits and help them to improve their pronunciation. But whereas the former is usually done for pleasure, intensive listening tends to be more concentrated, less relaxed, and is often dedicated not so much to pleasure as to the achievement of a study goal. Moreover, it is often done with the intervention of the teacher (Harmer 2007). 
More traditional recorded material (CDs, for instance) used in the classroom may also help to improve the students' listening skills, but in this case the students cannot see the speaking taking place. The great advantage of watching audiovisual clips is that they get to see 'language in use'. It is easy for them to see how intonation matches facial expression and what gestures accompany certain expressions, and they can learn a number of cross-cultural clues.

The introduction of technology and audiovisual materials in education has been intrinsically connected with the irruption of communicative approaches in language teaching contexts. The umbrella term "communicative approaches" (Widdowson 1978, Brumfit and Johnson 1979, Littlewood 1981, Krashen and Terrell 1983, Ellis 2003) gathers together different innovative approaches organised on the basis of communication. Under these approaches learning is thought to emerge through language production, and being able to communicate requires more than mastering linguistic structures, since language is fundamentally social.

Any truly communicative activity must have three features (González-Vera 2015: 72): information gap, choice and feedback as learners. Firstly, a text is communicative as it displays information that is unknown to the "reader". Communication exchange takes place as the participant has to understand the meaningful words or phrases of the message in order to fill the information gaps $\mathrm{s} / \mathrm{he}$ has. The activity is communicative insomuch that speakers have to choose what (content) and how (form) to reply to the other participants; in other words, they have to rely on their communicative competence, apart from their linguistic competence. Lastly, bearing in mind that communication is purposeful, the participants can evaluate whether or not the purpose of their message has been achieved by means of feedback, that is, the information reported by the listeners. These activities also have to be motivating and rewarding for learners. The students' interest in audiovisual texts lies at the root of considering the incorporation of audiovisual resources in learning-teaching environments. In addition, communicative approaches opt to expose students to natural language and advocate for the use of authentic language materials, as is the case of audiovisual texts. The use of animated TV series in the teaching of primary school teachers allows them to learn by means of authentic materials that deal with stimulating topics for their future students, namely, children. Therefore, the usefulness of these materials is beyond doubt. 


\section{RESEARCH METHODOLOGY}

\section{III.1. Data collection}

The group under analysis was Group 1 of English in Primary Education I, which included 37 students in their freshman year. This subject, taught in the Faculty of Education at the University of Zaragoza, was worth 6 ECTS, which entailed 150 hours' work for the student. 50 of them were class hours, distributed across lectures and seminars, and 100 hours involved autonomous learning.

In order to study the impact of audiovisual materials on the development of our students' communicative competence, we first collected qualitative data from a questionnaire designed for this purpose. The questionnaire (Figure 2) shed light on our students' relationship with English and their level of language in different skills.

It was composed of two parts. The first part included students' personal information such as their mother tongue, the time they had been learning English and their level of English. The second part of the questionnaire concentrated on the types of exercises they usually practise in and out of class, which could contribute to assess the relationship between their strengths and weaknesses in the different skills and the time devoted to training these abilities. The questionnaire concluded with questions related to the type of resources used by the students to train aural skills and identified the main pitfalls that learners encountered when listening.

Figure 2. Initial questionnaire.

\section{Surname, name}

2. Age

3. Gender

4. Country of origin

5. Level of studies accomplished (secondary school, vocational training, graduate, post-graduate, others)

6. Native speaker of...

7. How many years have you studied English?

8. How do you consider your level of English? (advanced, upper intermediate, intermediate, lower intermediate, beginner)

9. Where did you learn English? (You can choose more than one option): At school, at a private language school, private classes, in summer camps, 
travelling and meeting people, watching TV, seeing films, others.

10. How strong are your speaking skills in English? (advanced, upper intermediate, intermediate, lower intermediate, beginner)

11. How strong are your listening skills in English? (advanced, upper intermediate, intermediate, lower intermediate, beginner)

12. How strong are your reading skills in English? (advanced, upper intermediate, intermediate, lower intermediate, beginner)

13. How strong are your writing skills in English? (advanced, upper intermediate, intermediate, lower intermediate, beginner)

14. Have you got any English level certificate? (KET, PET, FCE, CAE, Trinity level, IETLS, TOEFL, others)

15. As a whole, what level of English do you think you have (according to the European framework)? (A2, B1, B2, C1, C2)

16. Can you speak any other foreign language(s)? Which? What level do you think you have?

17. Have you been to an English-speaking country? If so, where and how many times? Specify the duration of your stay there (Less than a week, from 1 to 3 weeks, from 3 weeks to 2 months, more than 2 months)

18. How frequently (hardly ever, not often, usually, always) do you do the following tasks outside class?

- Listening exercises

- Reading exercises

- Compositions

- Speaking

- Grammar and vocabulary

- Team work

- Others

19. Which of these activities do you most enjoy doing in class?

- Listening comprehension

- Oral presentations

- Debates

- Working in pairs

- Others

20. How often do you do listening tasks outside the classroom? (hardly ever, not often, usually, always):

21. What materials do you use? podcasts, CDs, video clips, others.

22. Do you ever use audiovisual materials outside the classroom? (hardly ever, not 
often, usually, always)

23. Do you like using audiovisual materials to improve your English? Why?

24. Which of the following problems may appear when someone speaks to you in English or when you do a listening comprehension activity. Indicate the frequency in each case (hardly ever, not often, usually, always).

- I don't understand many words and I get lost very soon

- It is difficult for me to identify the sounds in English

- I need to hear the text more than once if it is very long and I find it difficult to concentrate

25. How hard is it for you to understand (very easy, easy, hard, very hard):

- The listening exercises in your workbook

- Real conversations

- News and documentaries

- Radio programmes, podcasts

- TV series

The questionnaire was followed by two activities with which we attempted to improve our students' level in those skills that presented more difficulties. For the design of these activities, Jain's (2013: 79) suggestions for a positive framework for developing communication skills were taken into consideration:

Identify audience - Define the characteristics of your audience.

Select Topic - Define the topic, purpose, and scope of your communication.

Set objective and criteria - Set objectives to measure the outcomes and effect of your communication.

Gather information - Find sources and gather information for your communication.

Select medium - Decide what you will use to deliver your communication.

Develop structure of message - Create your message and determine how it will be best communicated.

Test and Revise - Practise, test, and revise communication.

Deliver communication - Send the communication.

In our case, the type of audience was future primary school teachers. As they would have to teach children, we decided to choose two animated television series aimed at children. Regarding the topic, these television series deal with issues which appeal to the target audience. On the one hand, our students needed to learn how to tell stories to their pupils and these series would present the main structures and expressions required 
for their future job; on the other hand, the subjects of these stories may be interesting and motivating for their pupils, thereby stimulating their desire to learn. The activities designed allowed them to practise communicative skills and to assess their success in communication.

\section{III.2. Data analysis}

All of our students were women aged 18 to 24 and most of them were Spanish, except for $5 \%$, who were Romanian and whose mother tongue was Romanian.

Although most of our students came from High School, a considerable number of them came from vocational training $(11 \%)$, which led to a heterogeneous group with different levels of English.

They reported having devoted a good number of years to the study of English: 10-17 years. Although the majority studied English at school and many of them took private classes, they also learnt English by watching TV (12\%), something that some years ago would have been unthinkable.

The questionnaire revealed that most of our students considered they were good at reading, whereas the percentages regarding their strengths in listening and speaking skills were more divided although the highest percentages move in low levels (Figure 3). $22 \%$ considered their listening and speaking skills basic and 38\% and 32\% lower intermediate in listening and speaking, respectively. One striking aspect was the high percentage $(57 \%)$ of students who did not have any certificate proving their level of proficiency in English, and those who did have a certificate had A2. However, when they were asked about their level of English, they thought they had B1.

The fact that $76 \%$ of the students had never been to an English-speaking country was very enlightening; information about their (low) level in other languages was also obtained, French being their first option as second foreign language. 
Figure 3. Level of listening, reading and speaking skills.

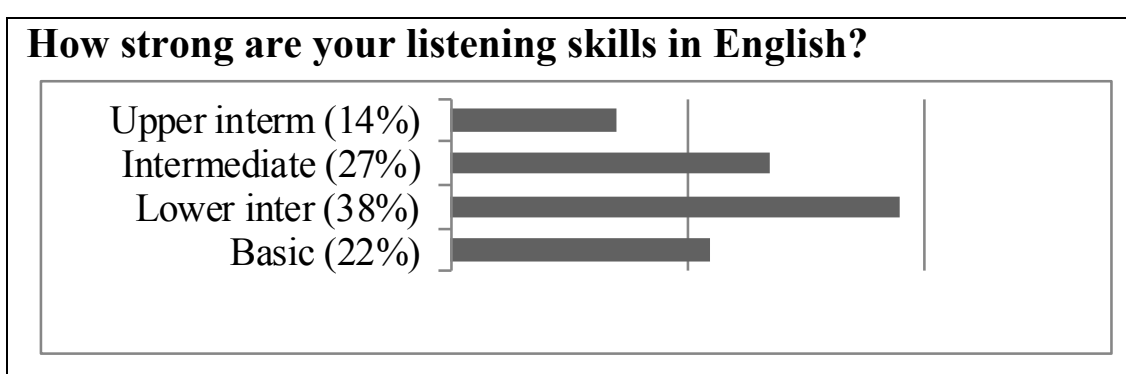

\section{How strong are your reading skills in English?}

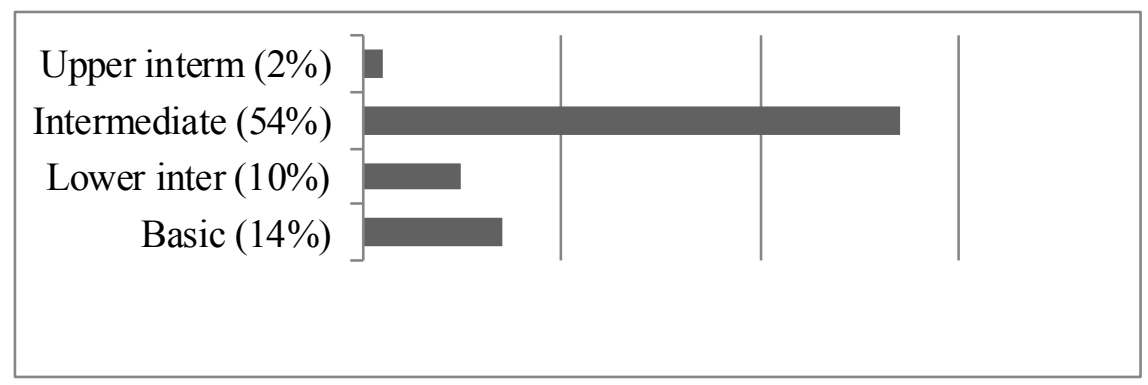

\section{How strong are your speaking skills in English?}

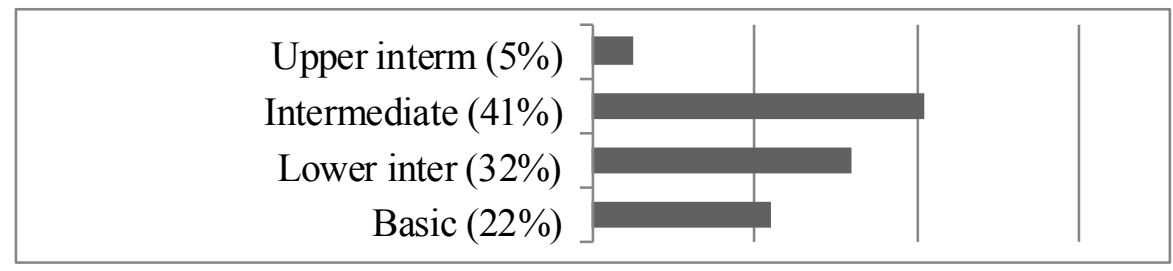

Students were also asked how frequently they do different types of activities in and outside class (Figure 4). The study reveals that students do not often do listening, speaking and reading exercises outside class, and none of them reported doing listening or speaking activities everyday outside class. In contrast, students are used to doing grammar and vocabulary exercises in and outside class. This leads us to think that students have been exposed to the Grammar Translation Method and not to the Direct Method, which implies a lot of practice of listening and speaking.

The questionnaire also confirms our suspicions that, in class, listening and speaking skills were underestimated with respect to the time devoted to reading, and grammar and vocabulary activities, even though the main aim of EFL lessons is to strengthen the students' communicative competences. In addition, although team work is fostered in class, as a consequence of the implementation of task-based learning, the number of 
times students do team work outside class is still low. However, the students reported they enjoy team work and working in pairs, which should be taken into consideration for the activities that are proposed to motivate students. The low percentages in oral presentations and listening comprehension activities as tasks that students enjoyed most led us to think that they are not presented in an attractive way. Students said that they associated listening comprehension activities with a passive activity in which an excerpt was played and their involvement was low; and the reason for disliking oral presentations seems to rest on the lack of guidance they are given while doing or preparing them.

Figure 4. Frequency in the practice of listening, speaking, reading, and grammar and vocabulary exercises in and out of class.

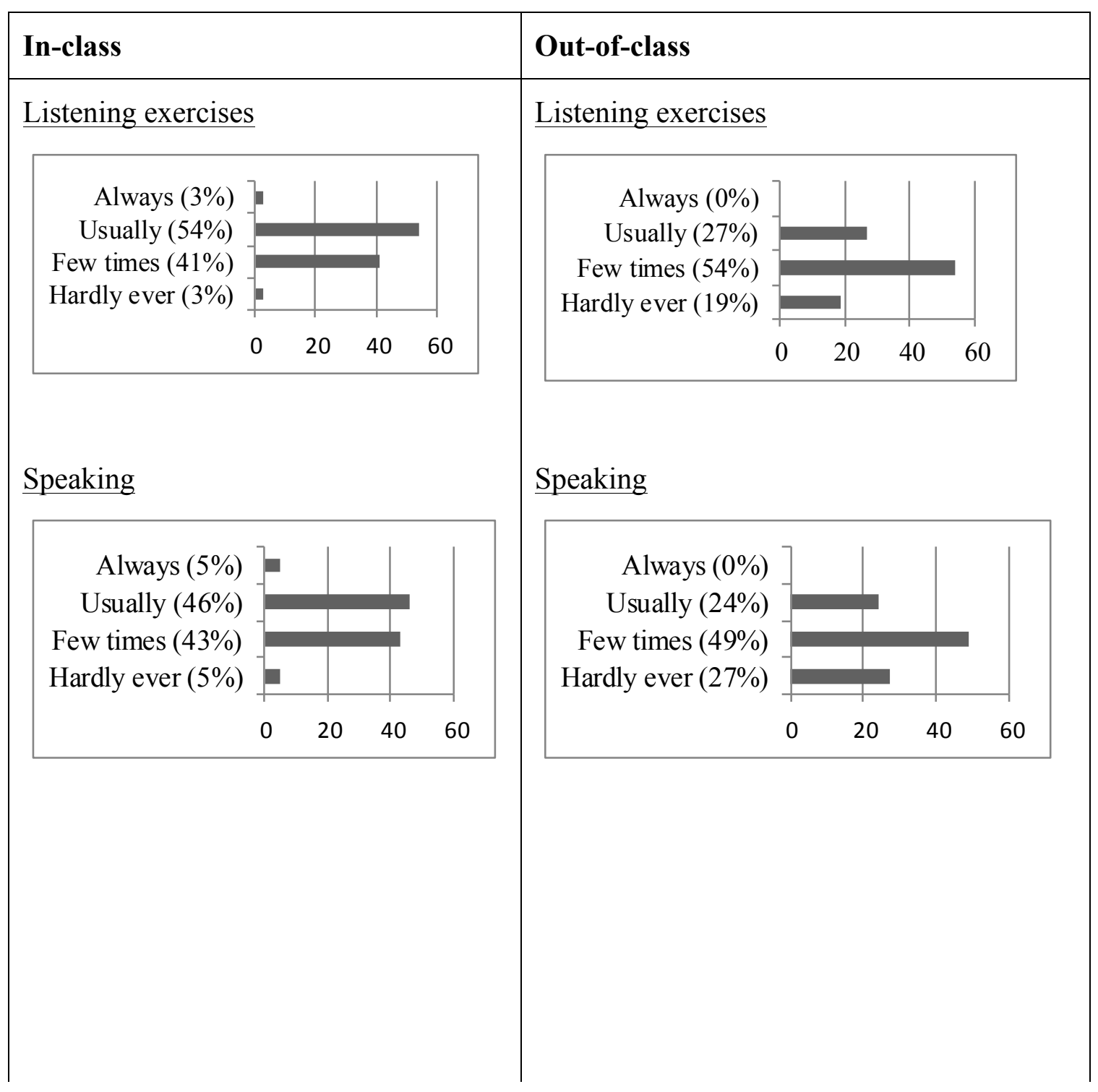




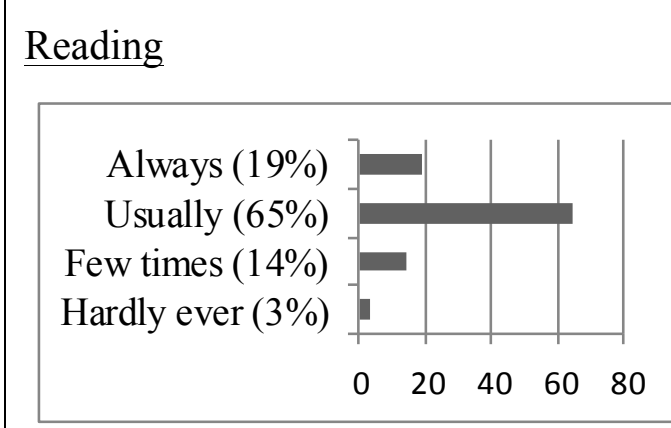

Grammar \& Vocabulary

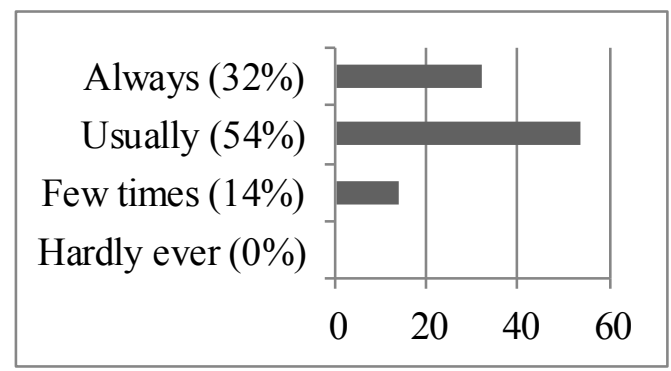

\section{Team Work}

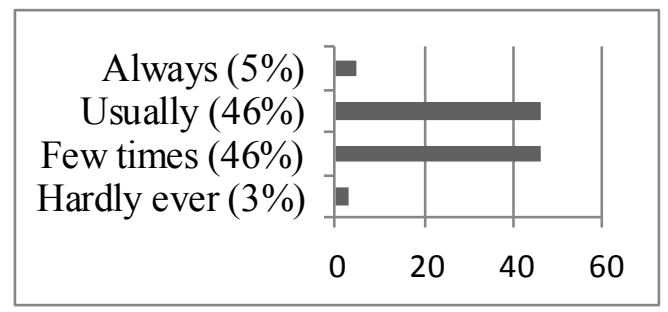

Reading



Grammar \& Vocabulary

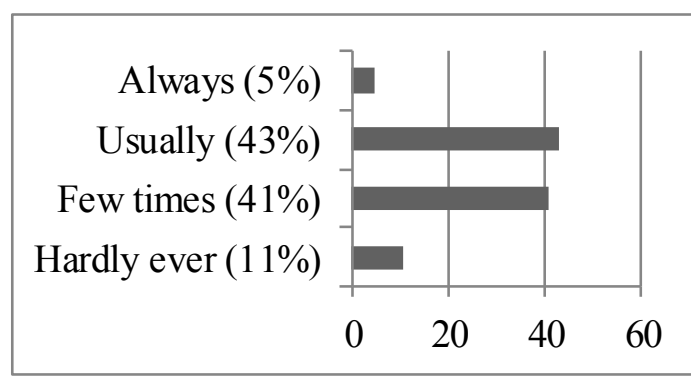

Team Work

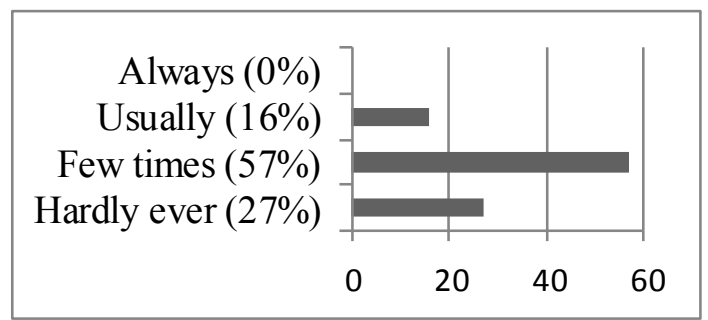

The use of traditional resources in class contrasts with the materials students tend to use outside class, video clips being the option preferred (30\%) (Figure 5). However, when asked about the frequency with which they use audiovisual materials outside class they stated they do not use them very often. Perhaps they have not been taught how to use them, since a considerable percentage (95\%) showed a liking for AV materials (Figure 6). Students said that they enjoy AV materials because they make the class more entertaining and catch their attention; it is easier to learn through AV materials and students are aware of their potential as a means to improve their accent and pronunciation. 
Figure 5. Type of materials used out of class.

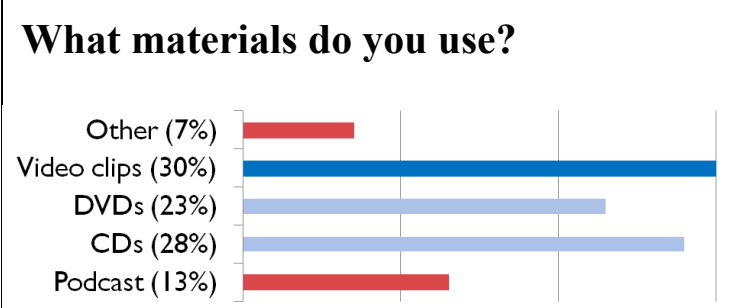

Figure 6. Frequency of use of audiovisual materials out of class and reasons for their introduction as part of the learning process.

\section{Do you ever use audiovisual materials outside the classroom?}



Do you like using AV materials to improve your English? Why?

. They make classes more entertaining

. They add interest, by attracting students' attention

. They make it easier to follow the class

. They help to improve your accent/pronunciation

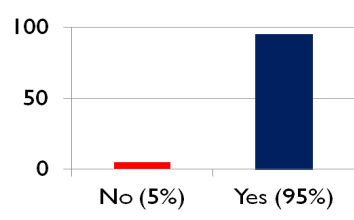

The questionnaire concluded with questions about the problems they have in a listening activity when they have to listen to someone speaking in English (Figure 7). Most of them said that they would need to hear the text more than once, something that may occur in an everyday situation (as when you ask the addressee to repeat a question that you have not quite understood). The second factor that makes comprehension difficult is the length of the texts. As they do not have any visual aid, they have to concentrate more on the oral message and they can get lost if it lasts too long. 
Figure 7. Frequent problems when someone speaks to you in English or when you do a listening comprehension activity.

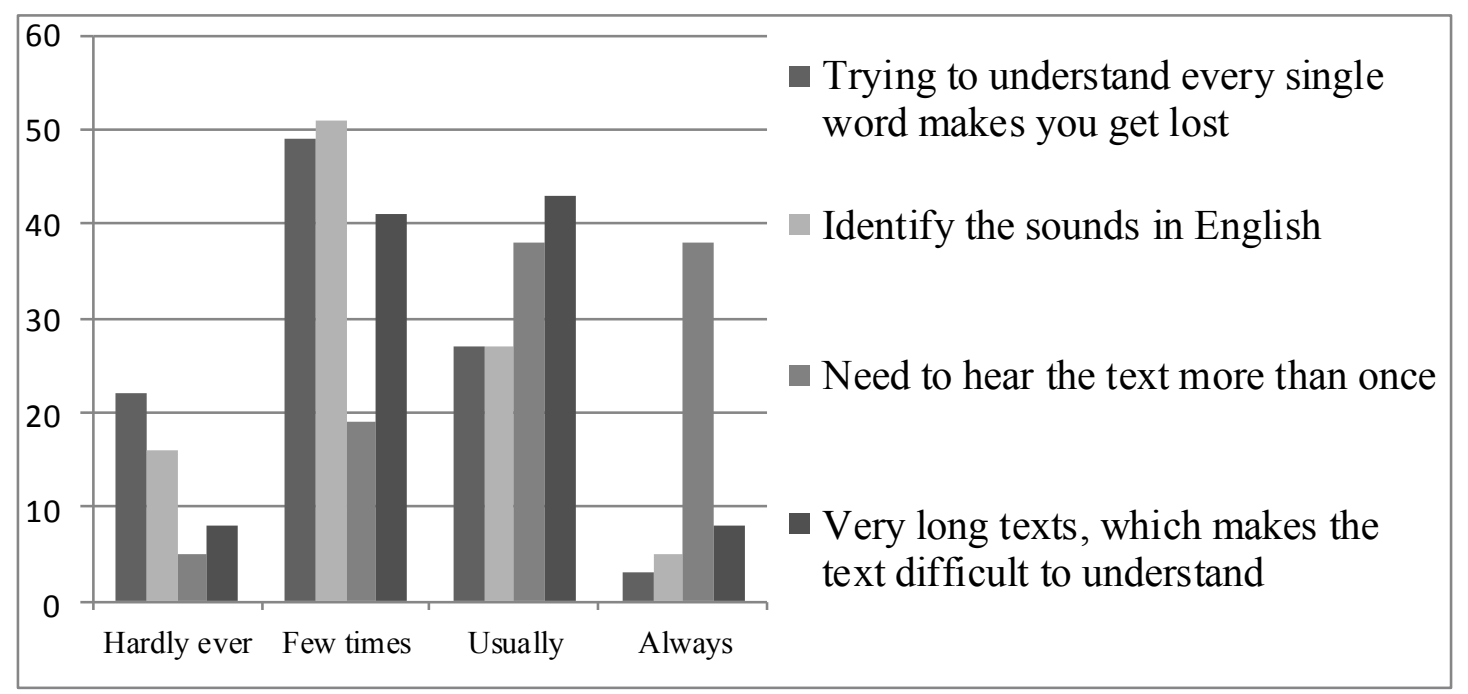

Conversely, the problem of understanding words and sounds, which one could think is the main pitfall for our students, is considered to be almost insignificant.

Finally, students were asked about the type of text they found harder to understand (Figure 8). The questionnaire revealed that the types of texts students find easier to understand are those taken from their workbook. This can be explained by the fact that these types of texts are "artificial", as they are "too perfect", clearly discernible accents are used, and few colloquialisms are found. Contrary to what it may seem, this is not an advantage, as we are not exposing our students to real situations.

News and documentaries, where technical terms pepper the text and a formal register is employed, followed by radio programmes, where students do not have any visual aid, are considered the most difficult texts in the students' opinion. 
Figure 8. Level of difficulty to understand different types of aural texts.

\section{How hard is it for you to understand...}

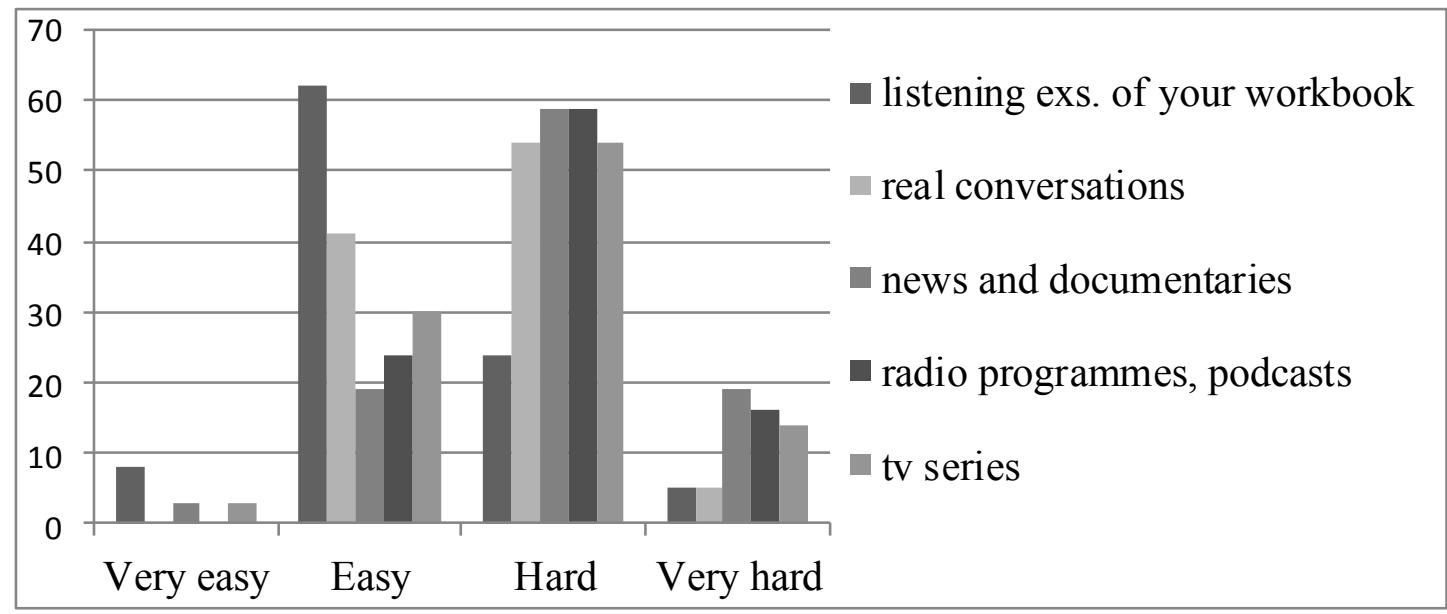

Easiest: Workbook exercises $>$ real conversations $>$ TV series $>$ radio programmes Most difficult: News $>$ radio/TV

Given the low level of language reported and the scant practice of oral skills (listening and speaking), two activities were designed in order to improve students' learning. These activities were based on the use of authentic materials and gave them the opportunity to develop strategies for understanding language as it is actually used.

\section{3 Activities and discussions}

\section{Activity 1}

The first activity (Activity 1) focused on the listening skills of our students and was aimed at the development of their comprehension when listening. The activity was included in Unit 2 of the subject English for Primary Education I. This unit was about the places and elements that can be found at school, such as the canteen, the playground, see-saws, slides, etc. and the students also had to learn how to tell stories, bearing in mind that they will be primary school teachers. 
Taking all this into account, we decided to use Peppa Pig and Ben and Holly's Little Kingdom as our texts. First of all, they were authentic materials that dealt with topics and issues related to the children's world, which could engage our students in the activity, and, secondly, their level of English was reasonable for our students, as the initial questionnaire revealed a general low level of English.

Activity 1 was made up of two tests. The first one evaluated the students' comprehension when the students can only listen to an audio track; and the second assessed their listening comprehension when the students count on all the elements they have in a real-life situation (audio, visual aid and contextual information). The first test (Figure 9) included two multiple choice listening activities, without any visual aid, and the episodes selected were 'Grandpa at the playground' (Peppa Pig) and 'The Frog Prince' (Ben and Holly's Little Kingdom). Thus, the topics of playground activities and elements, and fairy tales and their structure were covered.

Figure 9. Listening comprehension pre-test.

\begin{abstract}
A) You are going to listen to an episode of Peppa Pig. You will hear the recording twice. Indicate T (True), F (False) or DS (Doesn't Say). Only one answer is correct.
\end{abstract}

Peppa Pig. 'Grandpa at the playground'

1. Peppa Pig takes his grandpa to the park $\quad$ T $\quad$ F DS

2. Peppa's Grandpa didn’t like the roundabout $\quad$ T $F \quad$ DS

3. Grandpa's rules benefit the little ones $\quad$ T $\quad F \quad$ DS

4. The children end up making their own rules to go on the swing $\quad$ T $\quad F \quad$ DS

5. Mummy Pig suggests the same rule should work for all $\quad$ T $\quad$ F DS

B) You are going to listen to an episode of Ben and Holly's Little Kingdom (Ben \& Holly). You will hear the recording twice. 


\section{Ben \& Holly. 'The Frog prince'}

1. Ben is not allowed to go out to play T $\quad \mathrm{F} \quad \mathrm{DS}$

2. Ben is not very keen on using magic T $\quad \mathrm{F} \quad \mathrm{DS}$

3. There are twenty odd frogs in the pond T $\quad \mathrm{F} \quad \mathrm{DS}$

4. Holly and Violet identify Ben because he wears a waistcoat T $\quad \mathrm{F} \quad \mathrm{DS}$

5. Violet easily turns Ben back into an elf T F DS

In the Peppa Pig test, the students got an average mark of 6.6 and in the case of Ben and Holly's Little Kingdom, an average of 7, the total average being 6.8 (Figure 10).

Figure 10. Results of the multiple choice test WITHOUT visual aid.

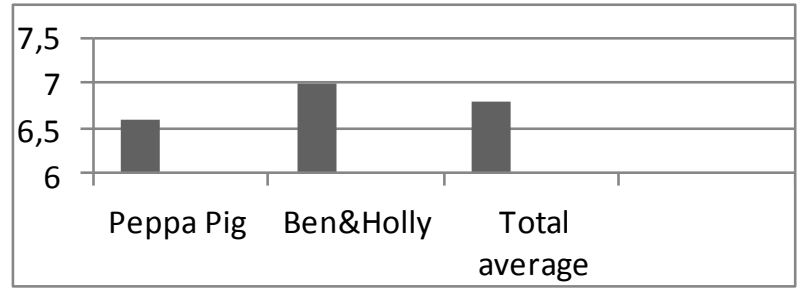

A few days later, another group of listening activities was presented to the same students (see below "Listening test"). These activities included multiple choice and gapfill exercises, the latter being more difficult, in the students' opinion. After the analysis of the results we could observe an improvement, 7.1 now being our students' average mark.

"Listening test"

\section{A) Peppa Pig. 'The Blackberry bush'}

You are going to see an episode of Peppa Pig. You will see it twice. Complete the sentences below with the correct information in no more than five words.

1. Peppa and her family are at Granny and Grandpa pig's house. Granny wants to make for dessert.

2. Mummy pig has been climbing the blackberry bush since 
3. But Mummy pig falls off the ladder and gets stuck in

4. That reminds Peppa of the fairytale of

5. Once the problem is solved, they all go and take the

\section{B. Peppa Pig. 'Bedtime Story'}

Instructions: You are going to see an episode of Peppa Pig. You will see it twice. Complete the sentences below with the correct information in no more than five words.

1. It is night time. Daddy pig reads Peppa and George a bedtime story. After a while, Peppa notices her little brother is still playing, so she makes up another story which begins, as usual, with the words: there was a little pig...

2. In the story, Georgie pig saw a little house in the forest, and inside the house there was

3. Peppa asks her little brother every now and then:

4. In the story, Georgie pig walks all around the world and finds a big green dragon with

5. The little friends in the story go back home

\section{Peppa Pig. 'Sports Day'}

You are going to see an episode of Peppa Pig. You will see it twice. Indicate T (True), F (False) or DS (Doesn't Say). Only one answer is correct.

1. Peppa argues that she is the fastest of all children T $\quad$ F $\quad$ DS

2. That Peppa is not the winner is not so important for her father T $\quad$ F $\quad$ DS

3. If George had not run, he would have jumped farther than Richard rabbit $T$ F DS 4. In spite of Peppa's reluctance, Daddy pig finally races in the relay 
in Peppa's team and does very well

T $\quad$ F $\quad$ DS

5. Finally the girls pull the rope hard and win

T F DS

\section{Peppa Pig. 'School Play'}

You are going to see an episode of Peppa Pig. You will hear the recording twice. Indicate T (True), F (False) or DS (Doesn't Say). Only one answer is correct.

1. Peppa's play group are going to put on a play: Little Robin Hood $\quad$ T F DS

2. Daddy Dog sounds very scary as a bad wolf $\quad$ T F DS

3. The teacher postpones photographing to the end of the play $\quad T \quad F \quad D S$

4. Pedro the Hunter does not help Grandma $\quad$ T F DS

5. Peppa is convinced she is the best actress $\quad T \quad F \quad D S$

Finally, the study concluded with the final exam of this subject (post-test), which included a listening test, consisting of two gap-fill exercises, one of them a story that followed the pattern of those seen in the previous activities. Students were not allowed to watch the clips but just listened to them twice. The length of the clips was three minutes, and they were used for the first (pre-test) and second activities (test).

The students' results for the listening part of the final exam revealed an improvement in the case of those who had participated in this study (students from Group 1). They got 7.5 as their final mark in the listening part. Their results were compared to those of the students belonging to Groups 2 and 3. While Group 2 included the students with the highest marks in Selectividad (University Access Exams), who also had another subject, Psychology, taught in English and had the intention of taking the speciality of foreign language in their final year, Group 3 was comprised of students with lower marks who came mainly from vocational training. The results from the comparison were satisfactory, as they showed how the marks of the monitored students were better than those of students in the other groups, the average mark in Group 2 being 7, and 6.4 in Group 3 (Figure 11). 
Figure 11. Comparison of the results of the listening test and comparison of the post-test results.

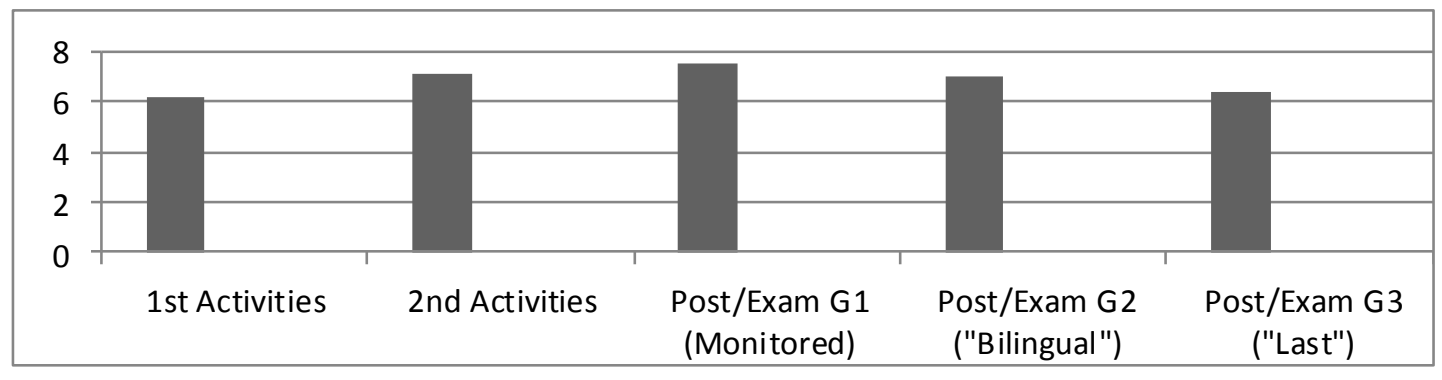

\section{Activity 2}

In the second activity students were given a script corresponding to an episode of Peppa Pig and another one of Ben \& Holly. They were asked, first of all, to read it aloud, paying attention to the pronunciation of the words and the intonation patterns required in the conversation. Then they recorded their readings and sent them to us. The episodes were:

\section{Peppa Pig. 'The Tooth Fairy'}

2. Ben \& Holly. 'Books' (the episode was edited, as it was originally too long) A few days later, the students watched the two episodes corresponding to the scripts they had read a few days earlier. They could watch them as many times as they needed and then they recorded their second reading. Finally they sent us the recordings. A total of 24 students sent the four readings (the complete set). The students were given simple instructions for the reading activity but no information concerning what was going to be analysed.

The interest of this activity was focused on pronunciation and to what extent it could improve after watching the two episodes. By 'improvement' we mean that the speaker's pronunciation came closer to the English sounds of RP, which is unquestionably linked with education, prestige and authority; it is the accent that is most intelligible to the British population as a whole (Honey 2000).

Our interest focused on the pronunciation of 10 phonemes which are particularly difficult for Spanish students of English. Six of them were found in the reading of the episode of Peppa Pig:

/dz/ as in 'George' $\quad / \mathrm{v} /$ as in 'visit' 
/i:/ as in 'leave' $\quad$ /j/ as in 'you'

$/ \Lambda /$ as in 'brush' final $/ g /$, as in 'pig'

and four in the episode of Ben \& Holly:

/s/ as in 'star' /h/ as in 'Holly'

/ $/$ as in 'shining' /ð/ as in 'that'

Then the pronunciation of the ten phonemes in the first and second reading was compared. Here follows the analysis of the results:

1. Peppa Pig. Where was the improvement detected?

In the second reading of Peppa Pig, after watching the episode, there was an improvement in pronunciation in 25 cases. The phonemes affected ('improved') were:

. from $/ \mho /$ to $/ \Lambda /$ in 'brush' (9)

. from /i/ to /i:/ in 'leave' (8)

. /j/ in 'you' (5)

. from $/ \mathrm{b} /$ to $/ \mathrm{v} /$ in 'visit' (2)

. from $/ \mathrm{j} /$ to $/ \mathrm{d} z /$ in George' (1)

Improvement represented $71.4 \%$ of all the cases where there was a change in pronunciation (35).

2. Ben \& Holly. Where was the improvement detected?

In the second reading of Ben \& Holly, after watching the episode, there was an improvement in pronunciation in 19 cases. The phonemes affected were:

. from epenthetic /e/ before /s/ initially to /s/ in 'stars' (7)

. from $[\mathrm{x}]$ (voiceless velar fricative to aspirated /h/ in 'Holly' (5)

. from plosive /d/ to the fricative / $/$ / in 'that' (4)

. from $/ \mathrm{s} /$ to $/ \mathrm{J} /$ in 'shining' (3)

Of all the cases where there was a change in pronunciation (24), improvement accounted for $79.1 \%$. This might lead us to interpret that the extent of improvement has 
been higher in this second practice, perhaps aided by the fact that the students had already gone through a previous 'training' process with the reading of the episode of Peppa Pig.

A number of students - six in each case - did not, however, vary their pronunciation in the second reading. In other words, $25 \%$ of the students tested did not modify their pronunciation in the second reading, in either case, (See Figure 12).

The data reveal that in some cases in the first reading of Peppa Pig our students did not pronounce the following phonemes properly and no improvement was observed in the second reading. This means that, in these cases, the students need to continue to practise in order to achieve a pronunciation that more closely resembles the sounds of English. Further pronunciation exercises (like reading word pairs or more audiovisual activities) would be helpful for that purpose. The phonemes that needed more practice were:

$. / \mathrm{v} / \rightarrow 79.1 \%$. The students did not differentiate $/ \mathrm{b} /$ and /v/ in words like 'very'.

$. / \mathrm{d} J / \rightarrow 70.8 \%$. The students did not differentiate $/ \mathrm{d} z /$ and $/ \mathrm{j} /$ in words like 'just' or 'George'. (They produced the phoneme / $\mathrm{j}$ / all the time).

$. / \mathrm{j} / \rightarrow 16.6 \%$. The students did not produce the phoneme $/ \mathrm{j} /$ in words like 'you'.

Instead, they uttered the palatal lateral approximant $/ K /$.

$. / \mho / \rightarrow 12.5 \%$. The students did not lower and centralise the phoneme to $/ \mathrm{N} /$ in words like 'brushing'.

. $/ \mathrm{i}: / \rightarrow 8.3 \%$. The students did not produce the long vowel in 'leave'. 
Figure 12. Phonemes that need improving (Peppa Pig).

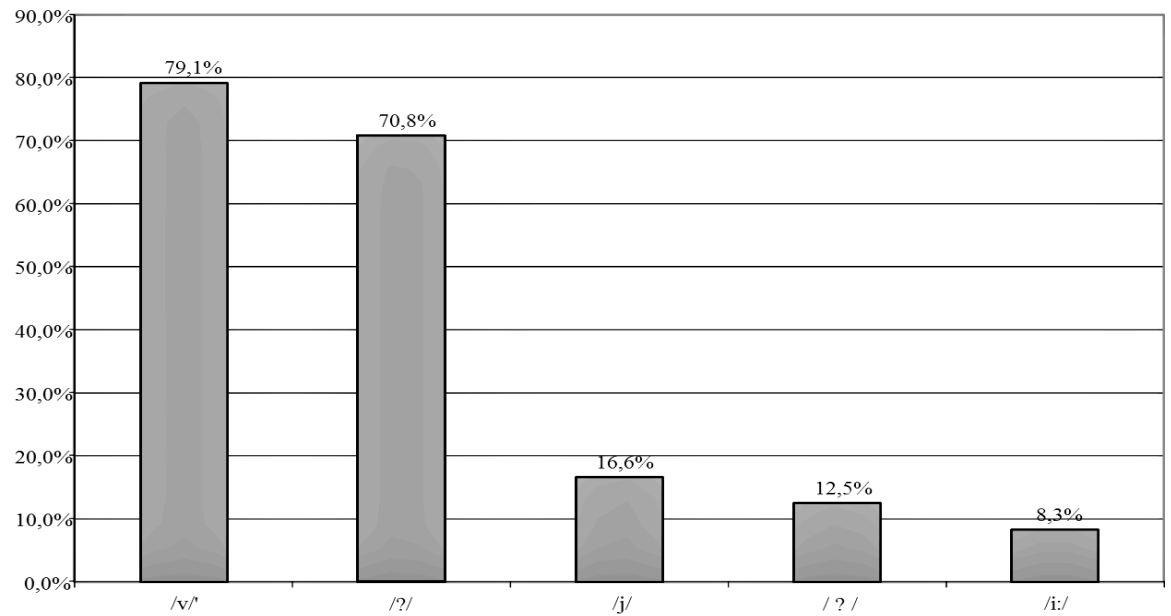

Likewise, in the first reading of Ben $\&$ Holly some of our students did not pronounce the following phonemes properly and no improvement was observed in the second reading. In this case, the following phonemes needed further practice (See Figure 13):

$/ \mathrm{J} / \rightarrow 58.3 \%$. The students did not differentiate $/ \mathrm{s} /$ and $/ \mathrm{J} /$ in words like 'shining'.

$/ \mathrm{s} / \rightarrow 50 \%$. The students produced the epenthetic /e/ before the initial /s/ in 'stars'.

$/ ð / \rightarrow 41 \%$. The students did not distinguish the pair /d/-/ð/ in 'that'.

$/ \mathrm{h} / \rightarrow 20.8 \%$. The students produced the $[\mathrm{x}]$ (voiceless velar fricative) initially, in the "Spanish way", instead of the English aspirated /h/ in 'Holly'.

Figure 13. Phonemes that need improving (Ben \& Holly).

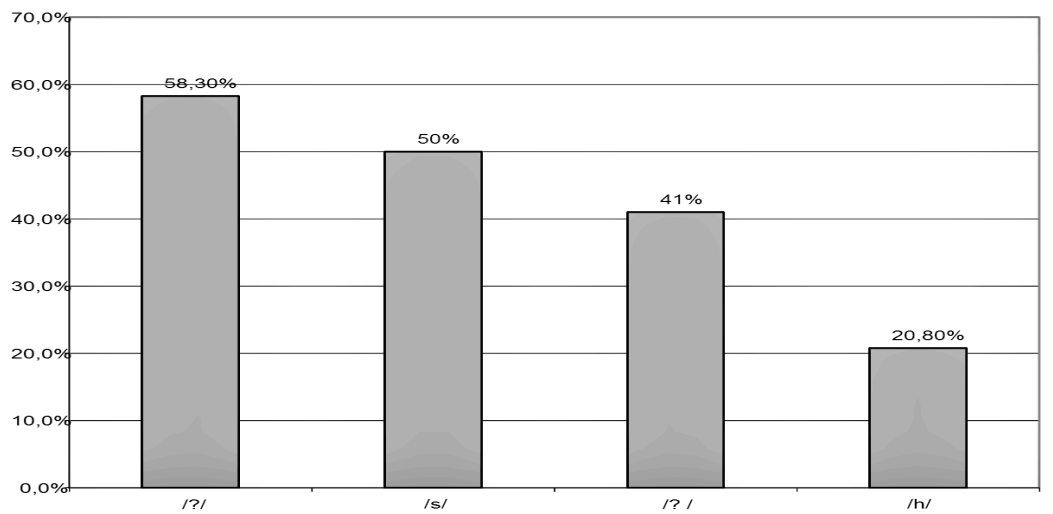

Therefore, as we have seen, in $75 \%$ of the cases there was a modification in pronunciation and, as pointed out previously, improvements were noted in $71.4 \%$ of cases in Peppa Pig and $79.1 \%$ in Ben \& Holly. 
Moreover, a clear improvement was perceived in the use of the appropriate intonation patterns. As we all know, intonation is a fundamental factor in speaking. It is used to show the grammar of what is being said (e.g., a falling tone indicating a statement, a rising tone a question), the speaker's attitude or a change in turn in conversation. However, it is difficult to learn and insufficient attention is devoted to its observation and teaching. One of the advantages of being exposed to watching videos is that students may raise their awareness of the power of intonation, a basic tool in every conversation.

\section{CONCLUDING REMARKS AND PEDAGOGICAL IMPLICATIONS}

In the case of the language training of primary school teachers, the use of animated television series allowed potential school teachers to learn by means of authentic materials that deal with stimulating topics for their future learners, that is, children. The choice of Peppa Pig and Ben and Holly's Little Kingdom seemed to be appropriate for the level of English in the class. Although, at first sight, one can think that the students might feel embarrassed or discouraged working with texts whose language level is not high and may be regarded as simple and naïve, the effect was the opposite. The students appreciated the use of authentic resources and saw these texts as potential materials for their pupils, which encouraged and motivated them.

The results were positive in both listening and speaking, as the final exam (post-test) revealed. While the progress in the case of listening was more remarkable, the improvement of their communicative skills was not so apparent. This could be justified by the profound lack of instruction in communicative skills during the students' previous training. Any improvement in these skills, however small it may be, encourages us to continue integrating the practice of using audiovisual materials, as it has proved to be so fruitful and rewarding.

Watching video clips allowed our students to improve their listening comprehension skills. The visual aid provided information that contributed to the full understanding of the message. As happens in real life, students completed what they understood aurally with what they saw; in other words, they filled in the missing gaps with visual information. Working with audiovisual texts also allowed our students to see language 
in use, that is, to relate paralinguistic behaviour to intonation, an effective way to learn a range of cross-cultural clues at the same time.

By training future teachers with these tools and activities - once it has been proved they are effective and motivating - we are paving the way for a more straightforward inclusion of these materials and technologies in the EFL teaching and learning process. Likewise, we are also ensuring the methodologies of foreign language teaching are updated - a demand made by students themselves.

\section{REFERENCES}

Brumfit, C. and Johnson, K. 1979. The Communicative Approach to Language Teaching. New York: Oxford University Press.

Crystal, D. 2006. "English worldwide". In Hogg, R. \& D. Denison (Eds.) A History of the English Language. Cambridge University Press

EAQUALS Bank of descriptors $<\underline{\text { http://www.coe.int/t/dg4/education/elp/elp- }}$ reg/Source/Key_reference/EAQUALSBank_levels_EN.pdf>



Ellis, R. 2003. Task-based language learning and teaching. Oxford University Press.

González-Vera, P. 2015. La evolución en el aprendizaje de idiomas, más allá de Internet. Verbeia, 63-74.

Honey, J. 1991.Does Accent Matter? London: Faber \& Faber.

Hornero, A., Mur-Dueñas, P. and Plo, R. 2013. "Oral skills in the spotlight: EFL in secondary education in a Spanish local context”. Synergy 9(2), 111-123.

Harmer, J. 2007 (4 ${ }^{\text {th }}$ ed.) The Practice of English Language Teaching. Harlow: Pearson/ Longman.

Jain, M. 2013. "Different techniques for developing communication skills". IRC'S International Journal of Multidisciplinary Research in Social \& Management Sciences, 78-82.

Krashen, S. \& Terrell. T. 1983. The Natural Approach. Oxford: Pergamon. 
Littlewood, W. (1981). Communicative language teaching: An introduction. Cambridge University Press.

Mur-Dueñas, P., Plo, R \& Hornero, A. 2013. “Spanish Secondary School students' oral competence in EFL: self-assessment, teacher assessment and assessment tasks". Miscelánea: A Journal of English and American Studies 47, 103-124.

Plo, R., A. Hornero \& Mur-Dueñas, P. 2014."Implementing the teaching/learning of oral skills in secondary education in Aragon: Gauging teachers' attitudes, beliefs and expectations". International Journal of English Studies 14 (1), 55-77.

Prenksy, M. 2001. "Digital Natives, Digital Immigrants". On the Horizon, 9 (5). 17 February $\quad 2015 \quad<$ http://www.marcprensky.com/writing/Prensky\%20\%20Digital\%20Natives, \%20Digital\%20Immigrants\%20-\%20Part1.pdf $>$

Tapscott, D. 2009. Grown up digital: How the Net generation is changing your world. New York: McGraw-Hill.

Widdowson, H. G. 1978. Teaching language as communication. Oxford University Press.

Received: 19 February 2015

Accepted: 21 February 2016

Cite this article as:

González-Vera, P. \& Hornero Corisco, A. 2016. "Audiovisual materials: a way to reinforce listening skills in primary school teacher education". Language Value 8 (1), 1-25 Jaume I University ePress: Castelló, Spain. http://www.e-revistes.uji.es/languagevalue. DOI: http://dx.doi.org/10.6035/LanguageV.2016.8.2

ISSN 1989-7103

Articles are copyrighted by their respective authors 